Notre Dame Law School

NDLScholarship

Journal Articles

Publications

1998

\title{
Natural Law and the Ethics of Discourse
}

John M. Finnis

Notre Dame Law School, john.m.finnis.1@nd.edu

Follow this and additional works at: https://scholarship.law.nd.edu/law_faculty_scholarship

Part of the Legal History Commons, and the Natural Law Commons

\section{Recommended Citation}

John M. Finnis, Natural Law and the Ethics of Discourse, 43 Am. J. Juris. 53 (1998).

Available at: https://scholarship.law.nd.edu/law_faculty_scholarship/872

This Article is brought to you for free and open access by the Publications at NDLScholarship. It has been accepted for inclusion in Journal Articles by an authorized administrator of NDLScholarship. For more information, please contact lawdr@nd.edu. 


\title{
NATURAL LAW AND THE ETHICS OF DISCOURSE
}

\author{
JOHN FINNIS
}

In launching (or relaunching on a sound basis) the philosophical discourse about natural law which has continued to this day, Plato explored with still unsurpassed penetration the ethics of discourse itself. For the dialogue of the Gorgias facilitates its readers' meditative appropriation both of morality's deepest sources (principia) and of the conditions for very significant kinds of action: truth-seeking dialogue, discussion or discourse, and meditation or reflective deliberation.

The framework of the dialogue satisfies the procedural conditions for fruitful discourse. The parties-Socrates and Gorgias, Polus, Callicles, and Chaerophon-are equals in freedom of status and of speech, ' unconstrained by any pressure for proximate decision and action, united in the mutual comprehension afforded by a shared and highly articulate and reflective culture, and assembled among free and equal fellow citizens who similarly are culturally united and (unlike, say, the audience for Socrates' apologia) unconstrained. And from the outset, and again and again, Socrates points to further conditions.

The first of those further conditions, ${ }^{2}$ the one most overtly articulated, is that the parties to discourse shall set aside speech-making and engage only in discussion, ${ }^{3}$ in which answer follows and responds to question and is not employed to block further questions. ${ }^{4}$ But there are other conditions, and Socrates, while indicating them here and there throughout the dialogue,

1. They meet and discourse in the city where there is "more freedom of speech than anywhere in Greece" (i.e. in the world): Gorgias 46le. Note: In general I quote from the translation by R.E. Allen, The Dialogues of Plato, vol. I (New Haven: Yale University Press, 1984). Allen's prefatory "Comment" on the Gorgias (ibid., 189-230) is valuable, not least his demonstration of the wide philosophical superiority of Plato's Callicles (not to mention Callicles' philosophical superior, Socrates!) to Nietzsche: ibid. 219-221; and his showing (206) that the fallacies in Socrates' arguments often denounced by modern commentators (cf. Terence Irwin, Plato: Gorgias [New York: Oxford University Press, 1979], v) are liable to be in the eye of the beholder.

2. Gorgias at $461 \mathrm{~d}:$ "observe one condition . . . bridle that long answer method."

3. Discussion: dialegesthai (447c-contrasted with "aperformance"; $449 b$-contrasted with "that lengthy kind of discourse [logōn] Polus began"; 453c-discussion as discourse motivated by desire to really know its subject matter).

4. Especially $449 \mathrm{~b}$. 
states them most summarily on the occasion when he also articulates the formal relation between truth and consensus under ideal conditions of discourse. Under conditions we today would call "ideal," Socrates/Plato affirms, persons engaged in discourse will agree: that is a mark of truth. ${ }^{5}$ The conditions? "Knowledge, good will, and frankness": (i) a sound, wide-ranging education; (ii) good will towards the other parties to the discourse/discussion (indeed, the kind regard one has towards one's friends); and (iii) willingness to speak frankly (even when that involves admitting one's mistakes, self-contradictions, and self-refutation), and not to feign agreement. ${ }^{7}$ In the absence of these conditions, even universal assent to a proposition would be no evidence (let alone a guarantee) of its truth. ${ }^{8}$ And when the conditions are fulfilled, the discussants' convergence is not a criterion of truth, a standard to which one can appeal to discriminate, within argument, between sound and unsound judgments. Rather it is a mark of truth, a welcome and confirmatory consequence of their common willingness to attend to what every truth-seeking discussion must have as its objective: "things which are" (the truth of the matter) (ta onta)," what "is so,"10 "what is true and false concerning the matters of which we speak-for it is of common good to all that the thing itself become manifest." But this reality to which true propositions correspond is not something accessible or intelligible (still less is it adequately imaginable) otherwise than by question and answer, coherent, self-consistent thought, attention to all relevant evidence, all pertinent considerations. ${ }^{12}$ Nor, therefore, can there be any other

5. 486e5-6; also 487e, 513d. On "marks of truth," see the discussion of Wiggins in Finnis, Fundamentals of Ethics (Washington, D.C.: Georgetown University Press, 1983) 634.

6. Gorgias 487a2-3: epistēmē, eunoia, parrēsia.

7. 487a-e; see also 473a, 492d, 495a, 500b-c, $521 \mathrm{a}$.

8. See e.g. 472a, 475e. One must add what is not so often noted by those who speak of the "burdens of judgment" and the "fact of pluralism," that in nonideal conditions (i.e. all actual and foreseeable conditions) the absence of universal assent to, and the existence of widespread dissent from, a proposition is no evidence of its falsity.

9. $495 \mathrm{a} 8$.

10. $509 \mathrm{~b} 1$.

11. $505 \mathrm{e} 4-6$.

12. This article was written for a conference in 1998 on, and with, Jürgen Habermas. So it is worth noting here that Plato is scarcely a "Platonist" as that figure appears in Habermas's pages. Plato as I read him (and particularly the Plato/Socrates of the Gorgias) would assent without difficulty to the position which Habermas articulates thus (under the description "pragmatism"):

"Real" is what can be represented in true statements, whereas "true" can be explained in turn by reference to the claim one person raises before others by asserting a proposition. With the assertoric sense of her statement, a speaker raises a criticizable claim to the validity of the asserted proposition, and because no one has direct access to uninterpreted conditions of validity, "validity" (Gültigkeit) must be understood in epistemic terms as "validity (Geltung) proven for us." A justified truth claim should 
basis for rationally affirming or denying that "correspondence," in relation to any particular subject matter of discursive or reflective inquiry. ${ }^{13}$

The indispensable conditions on which discussion is worthwhile, then, can be reduced to respect-and-concern for the two human goods which Socrates/Plato keeps tirelessly before the attention of the reader of the Gorgias: truth (and knowledge of it), and friendship (goodwill towards other human persons). These conditions are rich and powerfully exclusive. The reader cannot fail to observe what Socrates never explicitly affirms: many of the participants in actual discourse-communities, not least (and not most) in wealthy democracies, do not meet those conditions. It is therefore impossible, I suggest, to justify a modern

discourse ethics [which] adopts the intersubjective approach of pragmatism and conceives of practical discourse as a public practice of shared, reciprocal perspective taking: each individual finds himself compelled to adopt the perspective of everyone else in order to test whether a proposed regulation is also acceptable from the perspective of every other person's understanding of himself and the world. ${ }^{14}$

The proposal that in discourse, and equally in choosing "regulations" of social life generally, we should "adopt the perspective of every other

allow its proponent to defend it with reasons against the objections of possible opponents; in the end she should be able to gain the rationally motivated agreement of the interpretation community as a whole.

Habermas, Between Facts and Norms: Contributions to a Discourse Theory of Law and Democracy, trans. W. Rehg (Cambridge, Mass.: MIT Press, 1996), 14. While assenting to all this, Plato, Aristotle, and the tradition would be inclined to add (quite reasonably) that there is a legitimate reflective inquiry into what it is about the world (including people) and rationality that makes possible this expectation that fully rational and reasonable people considering the relevant data would concur.

13. "The illusion which underpins most denials of the objectivity of ethics is this: that to which true judgments have their truth by corresponding ("the facts, "the world," "reality" ...) somehow lies open to an inspection conducted otherwise than by rationally arriving at true judgments of the type in question (scientific, historical, cryptographic . . . , and, why not? evaluative ...). That illusion is the root of all those reductive programmes which we call philosophical empiricism-programmes like those of Hobbes and Hume and successors of theirs . . .": Finnis, Fundamentals of Ethics, 64. Among those successors is, in his own curious way and despite his own intentions, Kant: ibid., 122-4. And, confronted by the assertion that, after an "irreversible critique" of metaphysics, this is a "postmetaphysical era," one should add "metaphysical" to the parenthetical list of types of true judgment (for the reasons indicated by Rawls, "Reply to Habermas," in Political Liberalism, paperback ed. [New York: Columbia University Press, 1996], 379n.)

14. Habermas, Justification and Application: Remarks on Discourse Ethics, trans. Ciaran P. Cronin (Cambridge, Mass.: MIT Press, 1993), 154 (emphases substituted). Habermas himself from time to time observes that "discourse ethics" envisages "ideal conditions . . . including . . . freedom of access, equal rights to participate, truthfulnesson the part of participants, absence of coercion in taking positions, and so forth": ibid. 56 (emphasis added), and (ibid.) a "cooperative quest for the truth." 
person's understanding of himself and the world" is incoherent. That is, it refutes itself in the manner Socrates explores and comments upon. ${ }^{15}$ For: some participants in discourse and in social life generally, perhaps many participants, understand themselves in more or less uncritical conventional patterns of thought picked up from the surrounding culture (perhaps under comforting descriptions such as "pious," "traditional," "enlightened," or "modern"). ${ }^{16}$ And some, perhaps many, understand themselves just like Polus and Callicles, in their different ways: as more or less covert admirers and desirers of power's gratifications and rewards, which they prefer to any interest in truth or friendship; they understand themselves as unconcerned, on principle (so to say), with the interests or perspectives of other people as such. "Perspectives" such as these should be, not adopted but rather rejected, for the sake of discourse (not demagoguery), truth (not mendacious or myth-ridden propaganda), friendship (not self-seeking flattery), and the real interests of all (including those wrongly interested in adhering to and acting upon their immoral "perspectives"). ${ }^{17}$

Does that entail that Plato/Socrates' own willingness to discourse on friendly terms with Polus and Callicles, these inward admirers of tyranny, is itself performatively inconsistent? By no means. While they are at all willing to listen, he can and will try to illustrate and explain, to them as well as to any bystanders of goodwill, the worth-the desirability-of a friendship (including a public politics) based on shared acknowledgement and respect for intrinsic human goods such as truth and (such) friendship. Such goods can be elements of a common good.

That the good of truth, and of getting to know it for its own sake, is one among these basic aspects of that human well-being which can be truly common (a koinon agathon) ${ }^{18}$ is a truth which Socrates finds dozens of

15. E.g. Gorgias 495a, 509a.

16. Habermas himself, of course, is well aware of this, and from time to time emphasizes it strongly. But I have failed to discover the basis on which he supposes that this fact is compatible with reaching moral conclusions by the method he recommends (scil. of adopting the perspective of every other person's understanding of himself and the world). It is one thing to favor the true interests of each and every person, quite another to favor or adopt the self-understanding of those who do not know or do not care what is truly in their interests.

17. So we must read with due reserve Aquinas' (Aristotle's) generous-minded praise of his opponents in discourse; it is due only on the assumption of their goodwill, an assumption often falsified in other contexts. Sententia super Metaphysicam XII lect. 9 n. 14:

Since, in choosing what to believe and what to reject, we ought to be guided more by truth's groundedness than by affection or illwill towards those who hold an opinion, so we should love both those whose opinion we follow and those whose opinion we reject - for they each were seeking to inquire after truth, and each assisted us to do so.

18. Gorgias 505e6, quoted above at n. 11 . 
ways to assert. If his assertions leave Polus and Callicles unimpressed, they perhaps do not fail to move the old sophist Gorgias. ${ }^{19}$ Indeed, as Plato intended and in some measure foresaw, they are appeals over the heads (and under the guard) of unreasonable people to anyone willing to listen. (And the division between unreasonable and reasonable people is also a division within one's own-in practice, everyone's-individual mind-and-will.)

Considered as the benefit to be gained or missed in a discussion (or a course of reflection), truth is a property of the judgments to be made by those (or the one) engaged in the common (or solitary) inquiry. So, existentially, it is the good of understanding and knowledge. Its intelligible goodness, its character as not merely a possibility but also an opportunity, is grasped, in practice, by anyone capable of grasping that the connectedness of answers with questions, and with further questions and further answers, is that general and inexhaustible possibility we call knowledge. This grasp of a field of possibility as a field of opportunity originates in an act of that kind of undeduced (though not datafree!) understanding which C.S. Peirce, in common with the tradition originated by Plato, calls insight. ${ }^{20}$

If one set out to argue- to contend in discourse or in one's private reflections-that truth (and knowledge of it) is not an intrinsic good, desirable for its own sake as the avoidance and overcoming of ignorance, muddle, and error, one would refute oneself. ${ }^{21}$ One's argumentative

19. See 506a.

20. See e.g. Justus Buchler, The Philosophy of Peirce (London: Routledge and Kegan Paul, 1940), 304, a passage in which Peirce, italicizing the word "insight," speaks of "the abductive suggestion [which] comes to us like a flash" as "an act of insight." Peirce's emphasis on the fallibility of the thought which thus emerges is entirely compatible with the Aristotelian thesis (e.g. Aquinas, Summa Theologiae I q. 85 a. 6) that insight (nous, intellectus) is intrinsicallyinfallible; for in every particular instance, what strikes one as sheer insight (which could not but understand matters as they are) may in fact be a mere "bright idea," distorted by oversight, imaginative fantasy, and/or prior or subsequent fallacious reasoning. Always, bearing this possibility of error in mind, one must go beyond simple insight to judgment (itself a matter of insight into the fulfilment of conditions of adequacy to the data, validity of argumentation, etc.). Even basic insights into first principles are appropriately reviewed and defended by what the tradition calls "dialectic." So "wisdom" is a matter not only of drawing conclusions from, but also of making judgments about, indemonstrable first principles, and of rebutting (disputando) those who deny them: Aquinas, Summa Theologiae I-II q. 66 a. 5 ad 4; Finnis, Aquinas: Moral, Political, and Legal Theory (Oxford: Oxford University Press, 1998), 88. (Underlying Kant's allegedly "good grounds for abandoning the Aristotelian concept of judgment" (Justification and Application, 17) is "the vestigial empiricism so often denounced in Kantian thought": Bernard J.F. Lonergan, Insight (New York: Philosophical Society, 1957), 154, 339-42; cf. Finnis, "Historical Consciousness" and Theological Foundations (Toronto: Pontifical Institute for Mediaeval Studies, 1992), 16. R.E. Allen, The Dialogues of Plato, vol. I, 220, puts the root of the matter straightforwardly-though "insight" is a better term than "intuition": "Assuming without argument the nonexistence of intellectual intuition, on which the classical tradition in metaphysics is based, [Kant] undertook to prove that what he called theoretical reason is powerless in metaphysics and ethics. ...")

21. Finnis, "Scepticism, Self-refutation and the Good of Truth" in P.M. Hacker and J. 
(seriously asserted) denial would be performatively inconsistent; what is asserted would be inconsistent with what is instantiated in and by the activity of seriously asserting it, arguing for it, proposing it for acceptance.22 The bringing to light of such performative inconsistency is one, but only one, of the kinds of refutation (elenchos) which Socrates employs and which Callicles vainly urges him to abandon. ${ }^{23}$ Refutation of this particular kind is not, to be sure, a strict demonstration of the truth which the self-refuting assertion denies; ${ }^{24}$ it is rather a cogent defense of that truth-in this particular case the truth that knowledge is a basic human good-against any serious denial. And it is a form of defense peculiarly

Raz, eds., Law, Morality and Society: Essays in honour of H.L.A. Hart (Oxford: Oxford University Press, 1977), 247-67.

22. Ibid., 251, behind which lie G. Isaye, "La justification critique par rétorsion," Revue philosophique de Louvain 52 (1954) 205; J.L. Mackie, "Self-refutation-A Formal Analysis," Philosophical Quarterly 14 (1964) 195-6; Joseph M. Boyle, Jr., "Self-referential Inconsistency, Inevitable Falsity and Metaphysical Argumentation," Metaphilosophy 25 (1972) 25-42. See also Finnis, Natural Law and Natural Rights (Oxford: Oxford University Press, 1980), 73-5, 79-80; Joseph M. Boyle, Germain Grisez, and Olaf Tollefsen, Free Choice: A Self-referential Argument (Notre Dame, Ind.: University of Notre Dame Press, 1976), 122-38. For an example of self-refutation in the attempt to exclude insights of the kind articulated in what the tradition called principia per se nota (general propositions foundational to reasoning in a given domain; self-evident [though neither data-less nor dialectically indefensible] principles), consider Habermas, Between Facts and Norms, 226:

Substantial reasons can never "compel" in the sense of logical inference or conclusive evidence. The former does not suffice for justification, because it merely explicates the content of the premises, whereas the latter is not available except in the case of singular perceptual judgments, and even then it is not beyond question. Hence there is no "natural" end to the chain of possible substantial reasons; one cannot exclude the possibility that new information and better reasons will be brought forward. (emphases added)

Here Humean empiricism and Vienna positivism take a new form, but remain as always incoherent both with their own claim and with the intelligence deployed in articulating them. In particular, Habermas is seeking to exclude in advance precisely what he says cannot be excluded, viz. the possibility that "better reasons will be brought forward" to show that, e.g., truth and friendship have intrinsic worth and are constituents of the "natural end to the chain of possible substantial reasons," and that this truth about truth and friendship is unrevisable. (Note: I am not denying that there are differences in the way in which various types of good-and-sufficient reasons "compel" assent; in some types of instance, assent can (psychologically) be withheld and so depends upon one's dedication to truth. See Finnis, Aquinas, $11 \mathrm{n}, 87-8$.)

23. "Dear friend [Socrates], be persuaded by me. Cease from refutation (elenchōn) and practise the music of affairs (pragmaton). Practise that which will make you seem wise (doxeis phronein).... Do not emulate men who practise refutation (elenchontas) in these petty matters, but rather those who possess life and glory [reputation] (doxa) and many other goods": Gorgias 486c-d.

24. See e.g. Aquinas, Sententia super Metaphysicam IV lect. 6 n. 14 [609]: elenchus or argumentatio (which Aquinas thinks would better have been called redarguitio, selfrefutation: n. 13 [608]) is "not demonstration simpliciter." 
and appropriately unsettling for the self-refuting skeptic, ${ }^{25}$ since what refutes his assertion is instantiated in his very own (inner or outward) act. This is not self-contradiction in the usual sense of asserting contradictory propositions (a contradiction from which one can escape by simply abandoning one or both of them). It is inconsistency, rather, between what one asserts (denies) and the data given, willy-nilly, by one's own very choosing to assert it. ${ }^{26}$ One's position is ridiculous, ${ }^{27}$ absurd; ${ }^{28}$ it is a vivid manifestation of that "discord with oneself" 29 which is involved in some measure in every kind of inconsistency, and which Calliclestestifying to its unacceptability-hopes to avoid by brutal frankness. ${ }^{30}$

In the logical domain of argumentation, self-refutation (whether by selfcontradiction or performative inconsistency) is a mode of refutation. In the existential domain of praxis it is an unworthy condition of truncated appropriation of truth, a kind of self-mutilating, a notable way of leaving oneself "limping and crooked" in psyche "due to falsity and pretence."31 The Gorgias strenuously insists (as does Habermas in his own way) upon the moral significance of the existential choice between concerning oneself with soundness in argumentation, in the hope of overcoming one's ignorance, incoherence, or blindness to what is so, and concerning oneself with success in (say) erotic/political affairs. ${ }^{32}$

25. Much "postmodernist" loquacity seeks to hide the irrationality, the surrender to evil, which persisting in performative inconsistency entails.

26. So it is, in the last analysis, a denial of evidence (data), and thus is less a question of logical incoherence than of turning away from or blindness to what is so, such as Socrates begged to be saved from even when it involved him in no logical inconsistency: "if I seem to any of you to agree with myself in something that is not the case, you must lay hold on it and refute me" (Gorgias 506a2-3). Illogicality is not the only, or even perhaps the most dangerous, obstacle to truth.

27. Cf. Gorgias 509a7.

28. $519 \mathrm{c} 4$.

29. See 482 b6. See also Plato, Sophist $252 \mathrm{c}$.

30. Gorgias 482d-483a.

31. See 525a2-3.

32. So Callicles loves and flatters both the demos and his lover Demos (481d, 513b-d), while Socrates takes care not to let the shifting opinions of his own beloved Alcibiades deflect him from the unchanging arguments of philosophy, his weightier love (482d). Or, as Callicles puts it, one should (and Socrates, he confidently-and, we know, mistakenly-thinks, in the end will) dismiss philosophy ("spending one's life whispering with three or four kids in a corner": 485e) in favor of the "free, important, sufficient" affairs of the courts, public and private business, and "human pleasures and desires," the whole voluptuous "music of affairs": 484d, 485e, 486c. Consider also the admission wrenched from the soul of Callicles, late in the discourse: "I don't know why, but you seem to me to make sense, Socrates. Yet I suffer the affection of the multitude. I don't quite believe you": $513 \mathrm{c}$. 


\section{III}

But in grasping the goodness, the intrinsic worth, of truth and knowledge of it, one grasps that it is a basic good not only for oneself but for anyone like oneself-a basic human good. Moreover, knowledge is not the only human possibility which, by insight into the data of one's inclinations and capacities, one grasps as an opportunity, an intrinsic good. Friendship, the sharing in goods with another or other persons each for their own sake, ${ }^{33}$ is another such good. For each and both of these reasons, one cannot reasonably seek a fulfilment which is only one's own. Because there is more than one intrinsic good, and also because one's pursuit of any basic good is threatened by more or less chaotic subrational desires, aversions, and inertia ("licentiousness"34), one needs look to establishing and confirming order in one's soul: a temperate (including courageous) ${ }^{35}$ will and character. Because one's pursuit of fulfilment would be unreasonable and selfmutilating if it were indifferent to friendship and to the worth of the instantiation of human goods in the lives of other people, one needs look to getting order into one's relations with one's fellows, one's communities. The name for that order, and for one's constant concern for it, is justice. ${ }^{36}$

The recognition of human equality which (as Plato/Socrates makes plain) is the core of a just will ${ }^{37}$ is nothing other than the recognition that basic human goods are realizable as much in the lives of other human beings as in my own life. To refuse that recognition is to be buried in untruth. No one thus enslaved to error can intelligently think himself happy; to think so would be to bury oneself deeper in untruth, untruth about what fulfilment is. Properly (rationally) understood, knowledge, friendship, fulfilment, and justice are inter-defined. So it is a mistake, and one avoided by the tradition founded by Plato and his followers (say, Aristotle and Aquinas), to think that there is within practical reason an "ethics" concerned just with "how

33. Not to be confused with the unilateral "altruism" introduced by Comte. Since friend A wills the good of friend B for B's sake, and B the good of A for A's sake, A must will also his own good (for B's sake) and B his own good (for A's sake), so that each is raised to a new standpoint, concern for a truly common good. See Finnis, Natural Law and Natural Rights, 142-4, 158; Aquinas, 111-17.

34. $507 \mathrm{~d}$.

35. 507b-c.

36. "I hold these things so and I say that they are true. But if true, then he who wishes to be happy must, it seems, pursue and practice temperance, and each of us must flee licentiousness as fast as our feet will carry us. . . This seems to me the mark at which we ought to look and aim in living; so to act as to draw everything of our own and of the city toward this, that justice (dikaiosyne) and temperance (sōphrosyne $\overrightarrow{\text { ) }}$ shall be present to him who is to be happy. He must not permit unchastened desires to exist or undertake to fulfil them, for then an endless, aimless evil will be his, and he will live the life of a robber ... dear neither to god nor to any man, for it is impossible to live in association (koinonein) with him, and where there is not association (koinōnia), there is no friendship." 507c-e.

37. See e.g. $489 \mathrm{bl}$ (dikaion to ison); $508 \mathrm{a} 6$ on geometrical equality as informing principle of justice. 
one sees oneself and who one would like to become" and thus in a different domain from the "morality" of concern for "the interests of all."38

One cannot, then, have order in one's soul (will) without anticipating and doing what one reasonably can to promote and respect an order of equal justice in one's societies, one's associating or communion with one's fellows. And it would be folly to expect justice and friendship to exist in any society whose members are not concerned to promote and maintain such rational, desire-integrating order in their individual souls (wills). Moreover, just as no one could intelligently call a society good whose members treat each other as robbers treat their victims, so no one could intelligently call good the life of an individual who is enslaved to his subrational desires for gratification and thus, too, cut off from the reality, as opposed to spurious imitations, of friendship. In each type of case-the individual and the society-the order in question is good because it is intelligent and reason-

38. Cf. Habermas, "On the Pragmatic, the Ethical, and the Moral Employments of Practical Reason," in Justification and Application, 1-17; and n. 58 below. The incoherence of the distinction is made clear, it seems to me, by Habermas's exposition of it:

... ethical questions point in a different direction from moral questions: the regulation of interpersonal conflicts of action resulting from opposed interests is not yet an issue. Whether I would like to be someone who in case of acute need would be willing to defraud an anonymous insurance company just this one time is not a moral question, for it concerns my self-respect and possibly the respect that others show me, but not equal respect for all, and hence not the symmetrical respect that everyone should accord the integrity of all other persons. (Ibid., 6)

The compatibility of self-respect with this dealing with the insurance company cannot, I suggest, be rationally assessed without making "moral" judgments about the conditions on which property rights are justly respected and justly overridden, and about the injustice of fraud, and so forth. There is just one question: "how one ought to live" (492d4-5; 500c3-4) and one summary answer: temperately/courageously and justly (507d-e). (Nor, I believe, is it acceptable to assign Aristotle's ethics (moralia) to the supposed "ethical" (as distinct from moral) domain of practical reason, even with the qualification that the supposed individual ethos is supposedly for Aristotle "embedded in the polis" or in "the life historical horizon of a customary ethos" (ibid. 6, 10). Aristotle seems to me widely different from the "neoAristotelians," e.g. MacIntyre, whom Habermas regularly criticizes under that title; the criticisms are more acceptable than the assimilation of their culture-relativism to Aristotle, whose Nicomachean Ethics soon makes clear that it is aimed against the view ("people think") that "the question of the morally admirable (to kalon) and the question of the just are ... the subject of such variety and fluctuation that . . . they are matters not of nature but of mere convention": NE I.3: 1094 b14-17.) Likewise unacceptable, both as philosophy and as history of philosophy, is that way of distinguishing "good" from "right" which parallels Habermas's ethics/morality distinction and is presupposed in statements such as: "an Aristotelian approach ... views practical reason as limited essentially to ethical selfunderstanding and consequently to the sphere of the good" (ibid., 21). Justice is a virtue (a good of the person), but the "object," i.e. the very point of justice is the other person's right (ius suum), i.e. what as a matter of equality the other person-centrally (proprie), everyone alike (indifferenteromnibus)-is entitled to (quod ei secundum proportionis aequalitatem debetur): Summa Theologiae II-II q. 57 a. 4 , q. 58 a. 1 \& a. 11 , q. 122 a. 6). 
able and the corresponding forms of disorder are so far forth unreasonable and bad. And this appropriateness of good order in the individual and society is not something we just invent; rather, it becomes clear to us by experience, thought-experiment, discussion, rational judgment.

So, both because its desirability is discovered rather than dreamed up and because being reasonable is central to what we find ourselves to be (in potentia) and reasonably want to become and remain (in act), we can call this reasonable order in the soul and in society "natural"- something naturally good. And since in each type of case the good, reasonable, natural order can and must be picked out in the form of normative propositions directing one towards individual and social choices promotive and respectful of good order, the relevant directive propositions are appropriately called laws. (For law of any kind governs precisely by directiveness within the deliberations of its subjects.)

Thus Socrates/Plato transforms the Calliclean opposition between nature (physis) and law/convention (nomos) into the recognition of a natural law-the set of propositions which pick out (i) the goods (such as knowledge and friendship) ${ }^{39}$ to be pursued and (ii) the principles of reasonableness in realizing goods in the life of oneself and one's fellows-the principles of justice and the other virtues. ${ }^{40}$ The Calliclean/Nietzschean ${ }^{41}$ proposal to consider natural and therefore choice-worthy ("just by nature") ${ }^{42}$ the rule of the stronger, in ruthless pursuit of the desires they happen to find within themselves, ${ }^{43}$ ends in incoherence and self-refutation. The weak, in concert, are naturally stronger than the strong and subject him to their law and conventional wisdom of equality-based justice. ${ }^{44}$ Does

39. For attempts to identify a more or less full list of basic human goods and reasons for action, see Finnis, Natural Law and Natural Rights, 59-99; Finnis, Aquinas, 80-86; Germain Grisez, Joseph Boyle, and John Finnis, "Practical Principles, Moral Truth, and Ultimate Ends," American Journal of Jurisprudence 32 (1987) 99 at 106-115.

40. "... proper arrangement and good order of the soul have the name of lawfulness and law, whence souls become law-abiding and orderly; and this is justice and temperance ... [and] the rest of virtue. ...": 504d, e. ". . . there is a certain order properly present in each thing, and akin to it, which provides a good naturally suited to it. ..." Any authentic exercise of practical reason, such as a true art (techne) like medicine as distinct from a mere pleasure-oriented knack (empeiria) like pastry-cooking (500e5) or cosmetics or rhetoricalsophistic politicking-by-flattery (463b), "considers the nature (physin) of the person it serves and the cause [and nature (physin): 465a4] of what it does, and is able to render an account (logon) of each" (501al-3).

41. For a careful documentation of the close relationship between Callicles and Nietzsche, see E.R. Dodds, Plato: Gorgias: A Revised Text with Introduction and Commentary (Oxford: Clarendon Press, 1959), 387-91; for a brief but deeper philosophical assessment of Dodds's pages, and of the differences which are rooted in Nietzsche's postKantianism, see Allen, The Dialogues of Plato, vol. 1 , 220-221.

42. kata physin ... dikaiou: $483 \mathrm{el}$ (and therefore kata nomon . . physeous: e3); also 484bl (physeos dikaion), 488b2-3.

43. $482 \mathrm{e}-484 \mathrm{~b}$.

44. $488 \mathrm{~d}$. 
their natural strength entitle them to rule? Does anyone's? The "inference" from "is" to "ought" is obviously fallacious.

Again, proposing the "principle" that a worthwhile life consists in freedom from subjection to others turns out to be performatively inconsistent, for (as Callicles is brought to admit) it implicitly proposes living by flattery and demagogy, conforming more or less slavishly (if only for personal safety) to the desires of the many. ${ }^{45}$ And the "principle" that the content of the emancipated life is the search for satisfaction of all one's desires deprives Callicles of any basis for his own judgment that, say, the catamite's pathetic slavery-to-desire is unworthy. ${ }^{46}$ Its incompatibility, moreover, with the conditions of reasonable discussion (discourse) is made manifest, for readers of Plato's dialogue to contemplate at leisure, by the speech-making, the surliness, the sulky abdication from the to-and-fro of debate, and the not too veiled warnings that, outside the discussion, and after a trial by rhetoric not truth, Socrates' property may well be confiscated and he himself exterminated.

\section{IV}

In the discourse, of course, these warnings are merely argumentative, allusions to what, "in principle," is liable to happen to you if you adhere to the principle that "it is better to suffer wrong than to do it." Plato's reader, as Plato intended, knows more than the parties to the discussion. Knowing that the warnings were verified, one learns again that discourse is seamlessly integrated with the rest of practical life, and that one's conduct in discourse is morally significant, to be assessed by ethical (i.e. moral) as well as argumentative (i.e. logical) criteria. When one hears Socrates/Plato affirm the worth of truth, justice, and friendship and the worthlessness of lies, of injustice, and of the Calliclean/Nietzschean resolve to "be hard," one hears it knowing that Socrates chose to practice what Socrates/Plato discursively affirms. He did not lie in self-defense. ${ }^{47}$ (In taking that as exemplary, we need not so regard-nor, I think, did Plato so regard-every aspect of Socrates' trial advocacy.) And when we hear him affirm that doing injustice is worse than undergoing it, we know not only that he put this into practice but also that Polus and Callicles' allusions to this thought's unpopularity were to be verified in the event, and not just once:

45. 521a-b with 518a-d.

46. $494 c-e$.

47. Cf. Habermas, Justification and Application, 63: “On closer inspection, however, we find that negative rights and duties can no more claim 'absolute' validity than can positive duties. An untruthful statement that saves the life of another is no less morally commanded than killing in cases of self-defence. . . Valid norms are valid only in a 'prima facie' sense." See further, for this relaxed ethics of lying, ibid., 66 . 
... you decided to judge as a group the cases of the ten generals ... -illegally, as later it seemed to all of you. But at the time, I alone of the Prytanies opposed doing a thing contrary to law, and cast my vote against it. And when the orators were ready to impeach me and have me arrested-you urging them on with your shouts-I thought that with law and justice on my side I must run the risk, rather than concur with you in an unjust decision through fear of bonds or death.

Those things happened while the City was still under the Democracy. But when the oligarchy came, the Thirty in turn summoned me along with four others to the Rotunda and ordered us to bring back Leon the Salamanian from Salamis so that he might be executed, planning to implicate as many people as possible in their own guilt. ... Strong as it was, that oligarchy did not so frighten me as to cause me to do a thing unjust, and when we departed from the Rotunda, the other four went into Salamis and brought back Leon, and I left and went home. I might have been killed for that, if the oligarchy had not shortly afterward been overthrown. ${ }^{48}$

Perhaps the four who went off to fetch Leon for liquidation rationalized their complicity in murder by an ethics of "the situation," a "principle of appropriateness (Angemessenheit)".49 Or perhaps with the zest for thuggery of a Polus; or just with a more lofty Calliclean shrug. Perhaps, rather, they were decent people ashamed of what they. were doing, acknowledging each to himself - though not in "discourse" with anyone else-the injustice, untruth, evil of their choice. And since the consequences of Socrates' choice to go home are continuing, quite strongly, to this very day (e.g. through the hearts of readers of so many eras), we can judge how unreasonable it is to try to guide moral (i.e. ethical) judgment by an assessment of the "overall net balance" of premoral good and bad consequences "promised" by each of the options available in "the situation"-a situation which in reality includes our situation, so far away and so many centuries later. An ethics of "natural law" (rational principles) cannot embrace any moral methodology of the kinds proposed by utilitarianism (consequentialism, proportionalism) or by "situation ethics."

48. Apology 32b-d (trans. Allen, The Dialogues of Plato, vol. I, 95) (emphases added).

49. Cf. Habermas, Justification and Application, 14; see also 36-7,63-4 and passim (note the book's title). For a critique of ethical methodologies which propose to subject all norms, negative as well as positive, to a "test" of appropriateness to "the situation," see e.g. Finnis, Moral Absolutes(Washington, D.C.: Catholic University of America Press, 1993) 1624, 101-5; Finnis, Fundamentals of Ethics, 80-108; Finnis, Boyle, and Grisez, Nuclear Deterrence, Morality and Realism (New York: Oxford University Press, 1987), 238-72. 
Plato speaks through, and in a sense over, the dialogue, discourse, discussion of the characters he has communicatively set in motion. He is addressing the reflection, meditation, and eventually the inner deliberation of his readers, one by one. More radically than its being carried forward inter partes, discourse is in the reason and will of the individual. Would it not be quite a mistake to treat as "solipsism" the "monologue" which indeed is at the heart of any worthwhile dialogue $?^{50}$ It is in the outwardly silentperhaps only momentarily silent! - but intensely active contemplation of the reflective person that the worth of real friendship and the worthlessness of demagoguery and tyranny-and so too of inauthentic, flattering, or domineering discourse ${ }^{51}$-are understood and appreciated, and opportunities for participating in the one or the other are chosen or rejected. The will to seek advancement or protection by lying to one's fellows - and to become accomplice in their untruths-is preceded, commonly and "naturally" enough, by the self-deception of rationalization (not least in Calliclean types who tell themselves and others about their ruthless frankness). ${ }^{52}$

Without the return to oneself of reflection-without, that is to say, the inner appropriation, however speedy, of one's understanding's enhancement of experience, and one's grasp that the conditions for judgment are or are not fulfilled-discourse is "mere talk" or, worse, manipulation. ${ }^{53}$ And without a very resolute philosophical appropriation of the whole content of this inwardness one can scarcely appropriate the metaphysical truth to which one is inescapably committed by any rational affirmation of "the universalism of equal respect for all and of solidarity with everything that bears the

50. A sliding assimilation of "monological" to "solipsistic" seems to occur in the critique of Dworkin offered in Habermas, Between Facts and Norms, 224-5.

51. On sophistic (litigiosa) discourse, which in part is badly motivated (e.g. by desire to seem wise) and partly irrational (e.g. in refusing to concede anything which cannot be demonstrated stricto sensu), see Aquinas, Sententia in Metaphysicam IV.16 n. 12; Sententia Libri Politicorum. Il.2 n. 1[185]; Commentarium in Libros Perihermeneias I.9 n. 9; Expositio super Iob VI ad v. 29.

52. On inner evading (subterfugere) of truth, see Finnis, Aquinas, $11 \mathrm{n}$.

53. Moreover, as McInerny remarks (Ralph McInerny, ed., Aquinas against the Averroists: On There Being Only One Intellect [West Lafayette, Ind.: Purdue University Press, 1993]), 158:

However difficult philosophical inquiry may be, however scandalous the radical differences among sophisticated philosophical theories appear, the Aristotelian view is that communication and agreement are in principle possible because the discussants are human beings with common cognitive equipment and a common fund of experience.

The "Aristotelian view" is also Plato's. And McInerny's point is valid even in discourse with those who (not without, it seems, some complacency) regard "radical differences" not as "scandalous" but as a desirable and somehow in-built aspect of "modern life." 
mark of humanity." 54 Without that appropriation one will capitulate (as I later observe) to a delimitation of the "all," and of "humanity," a delimitation that has all too evidently been constructed in the felt interests of the strong, at even the most dramatic expense of the weak. So a community, too, has the responsibility of scrutinizing the results of such reflection, and of making and embodying in its highest constitutional law a correct judgment-not simply a consensus or democratically or judicially approved judgment ${ }^{55}$-about which beings are to be acknowledged to be members of the community. On so fundamental a matter of right, the normal criteria of legitimacy are, I repeat, supplanted by the overriding duty to define the boundaries of legal "personality" and right correctly.

We talk easily of Plato's authoritarianism. In part this marks our naivety in reading dramatic explorations of the foundations of ethics as if they were political manifestos or treatises. In part it is a mark (as I shall later say) of Plato's incomplete appropriation of the democratic implications of his own radical grasp of human equality in substance and in right. We likewise talk easily and dismissively of Plato's dualism, and this talk, too, is partly justified by weaknesses in Plato's philosophical armory, ${ }^{56}$ but more surely is also a mark of our own materialist naivety and fumbling inattention to reality. Most, perhaps everything the Gorgias says about soul as ground of human dignity and of an individual's most significant excellences or failures as a person is fully consistent with that personal body-soul unity which Aristotle and more resolutely Aquinas explicitly (and Plato surely, if not explicitly) brought to light by reflection on the experience, the inwardnessoutwardness of being in action.

In the act of (say) speaking to my partner in discourse, I understand my utterance as the carrying out of a choice which I made, and in the same act I am aware of my audible uttering, see the hearers register their comprehension, feel (say) confidence or anxiety, remember a past misunderstanding, and hope my statement will make my point. This experience of the unity (including continuity) of my being-as a feeling, willing, observing, remembering, understanding, physically active and effective mover or cause of physical effects and equally an undergoer and recipient of such effects-is a datum which philosophical exploration of human and other

54. Habermas, Justification and Application, 15.

55. E.g. Dred Scott v. Sandford, 60 U.S. 393 (1857).

56. I have in mind the aspect of Plato's writings about soul which Aristotle criticizes in De Anima, in particular the criticisms which Aquinas, in his commentary, summarizes allusively (In De Anima I lect. $8 \mathrm{n}$. 131): "soul shapes a body fit for itself; it does not enter a ready-made body. Plato and other philosophers, speaking only about the nature of soul, have given an inadequate account, failing to define which body goes with a given soul." This criticism can be summarized, again, as the complaint that Plato takes soul to be mover of body as sailors are movers of their ship, so that "soul is united to body not as form but rather as mover and director" (Aquinas, De Unitate Intellectus,c. 1 para. 5 [McInerny, ed., Aquinas against the Averroists: On There Being Only One Intellect, 23]). 
natural realities can adequately account for only with great difficulty and many a pitfall. Still, prior to all accounts of it, this intelligible presence of my many-faceted acting self to myself is a datum of understanding; one and the same I-this human being-who am understanding and choosing and carrying out my choice and sensing, etc., is a reality I already truly understand, albeit not yet fully (explanatorily, with elaboration). (Indeed, it is only given this primary understanding of one's understanding, willing, and so forth, that one can and typically does value such understanding, freedom, voluntariness, unity of being, and so forth.)

So, as Aristotle and (plainly) Aquinas argue more or less explicitly, ${ }^{57}$ any account proposing to explain these realities must be consistent with the complex data it seeks to explain, a set of data which includes the proposer's performance, outward and inward, in proposing it. The only account which meets these conditions will be along the lines they argue for: the very form and lifelong act(uality) by which the matter of my bodily make-up is constituted the unified and active subject (me myself) is a factor, a reality, which Aristotle (after Plato) calls psychē and Aquinas calls soul (anima). In the human animal - the very same animal whose interests in every individual case are to be taken equally into account, in Plato's as in the hopefully "postmetaphysical" ethics-from the very outset of his or her existence as human, it is this one essentially unchanging factor, unique to each individual, which explains (1) the unity and complexity of the individual's activities; (2) the dynamic unity in complexity -in one dimension, the program - of the individual's growth as embryo, fetus, neonate, infant . . . and adult; (3) the relatively mature individual's understanding of universal (e.g. generic) immaterial objects of thought (e.g. classes, or truth and falsity, or soundness/unsoundness in reasoning); and (4) this unique individual's generic unity with every other member of the species. In members of our species the one factor unifying and activating the living reality of each individual is at once vegetative, animal (sentient and self-locomotive), and intellectual (understanding, self-understanding, and, even in thinking, selfdetermining by judging and choosing). Though the manifold activations of these bodily and rational powers are variously dependent upon the physical maturity and health of the individual, the essence and powers of the soul seem to be given to each individual complete (as wholly undeveloped, radical capacities) at the outset of his or her existence as such. This is the root of the dignity we all have as human beings. Without it, claims of equality of right would be untenable in face of the many ways in which people are unequal.

This metaphysics of the activity of discourse, which cannot rightly be pushed aside as an outmoded "philosophy of subjectivity"-as if discourse could be undertaken or accounted for without the subjectivity of the

57. See Aquinas, De Unitate Intellectus III.3 [79]; Finnis, Aquinas, 177-9. 
deliberating and reflective subject-enables a theory of natural law to stabilize and clarify practical reason's undeduced grasp of first principles of the form "knowledge [friendship ... etc.] is a good for me and anyone (any being like me)." The same metaphysics is the indispensable basis for rationally affirming the core of the "natural law" account of right: one's choices and other acts and dispositions of will must be open always to integral human fulfilment, that is to the fulfilment of all human persons and communities. (This metaphysics is also the core of a fundamental account of language, in which intelligibility, corporeality, and sociality are uniquely unified as techniques and products available and perspicuous to spiritually organized living human organisms.)

\section{VI}

The distinction between ethics and morality turns out to be not merely (as I said) analytically unsound, a kind of category mistake ${ }^{58}$ (and a curious relic, as it seems, of Kant's oversight of the basic reasons for action). It also has bad consequences for Habermas's political-legal theory. For, as deployed in that domain, it has much the same role as Rawls's untenable distinction between "comprehensive doctrines" and "public reasons." In each case the author treats the distinction he has drawn as enabling him to set aside, but without seeking to refute, objections to legally permitting and authorizing the deliberate killing of very young or irreversibly damaged (unconscious?) human beings. Rawls, who in Political Liberalism introduced abortion as his one concrete illustration of how his "political liberalism" actually applies, shunts the objections to killing young unborn babies aside as being not within the alleged "overlapping consensus" or "reasonable." Habermas, who introduced the topics of abortion and euthanasia into a recent "Reply to Critics," shunts similar objections aside as being merely "ethical" and thus concerned, not with what is required by a morally indispensable respect for the interests of all as equals, but only with what is "best for us" (i.e. for the partisans of this or that ethical opinion). Thus he cuts himself off from the very meaning of the discourse of his partners in discourse, or at least so radically misconceives their views that civil conversation with them is substantially obstructed. And above all he thus proposes a quite fallacious justification/rationalization for abandoning very many of our fellow human beings, by legally authorizing the intentional termination of their lives. In doing so, he abandons his own fundamental "moral" thesis that decisions must be taken in the interests of

58. A rather serious mistake, I think; the bifurcation between these supposed domains of practical reason, and the thought that "ethical" reason is naturally egocentric (unless ethnocentric) (see e.g. Between Facts and Norms, 97), are very damaging both to ethical/moral understanding in general and to the specifically vocational choices and commitments which one must make for oneself by choices between options none of which is ruled out by the general principles of morality. 
all; he lays aside his own "appeal to an ever-wider community." 59 This, it seems to me, is a diskursethische debacle worth observing in some detail.

The killings in question are those involved in euthanasia and abortion. The examples are brought forward by Habermas without explication. I shall assume that by "abortion" is meant cases of induced termination of pregnancy which on one view are wrongful because they intend the death of the unborn; and that by "euthanasia" is meant killing on the ground that the life of the person to be killed is no longer worth living (say, because of irreversible unconsciousness). ${ }^{60}$

Notoriously, such killings and the question whether they are immoral and should be legally prohibited are the subject of a rather intense public discourse. Habermas contends, however, that this discourse concerns "the ethical question of which regulation is respectively 'best for us' from 'our' point of view." This enables him to say that, when discussion has shown that the disagreement "cannot be resolved either by discourse or by compromise," then the matter must be raised to a new "level":

Each participant must turn away from the ethical question. . . . They must, instead, take the moral point of view and examine which regulation is "equally good for all" in view of the prior claim to an equal right to coexist. ${ }^{62}$

The "all" for whom the regulation is to be "equally good" do not, it appears, include the unborn or the irreversibly unconscious, but rather the "all" comprising those who want or "need" to choose these killings, all those who oppose them, and all who look on more or less indifferently. The "equal right to coexist" is emphatically not the "equal right of the unborn and the permanently unconscious" which those on one side of the so-called "ethical" debate had been asserting. No, indeed. Anyone on that side of the debate must now-in virtue of the other side's "right to coexistence"-stand aside to let people on the other side opt for the killings they (often, no doubt, reluctantly) propose:

... the normative expectation connected with this-that when necessary we tolerate the members of another group whose behaviour is ethically reprehensible to "our" view-does not necessarily imply any damage to our integrity: "we" (for instance, as Catholics confronted by a "liberal" abortion law) may continue at an ethical level to abhor the legally permissible practice of others as we have in the past. Instead, what is 1486.

59. Habermas, "Reply to Symposium Participants," Cardozo Law Review17 (1996) 1477,

60. It should be observed that Habermas finds personally rather "unbearable" the practice of euthanasia as it would-given certain assumptions about public opinion-be required by his position to be legally and socially permitted: ibid. at 1490 .

61. Ibid.

62. Ibid. 
legally required of us is tolerance for practices that in "our" view are ethically deviant. ${ }^{63}$

But all this distorts almost beyond recognition the actual and historical discourses on abortion, euthanasia, and their legalization. When the most recent British parliamentary committee report on euthanasia explained its unanimous rejection of legalized euthanasia or assisting in suicide, it did so precisely on the ground of right:

society's prohibition of intentional killing ... is the comerstone of law and social relationships. It protects each one of us impartially, embodying the belief that all are equal. ${ }^{64}$

When Peter Singer and I discoursed publicly on these matters at the Philosophy Society in Oxford in May 1998, it did not for a moment occur to us or, I daresay, to any of the many philosophers in the room that either of us was discussing what is "respectively 'best for me/my group' from "my/my group's point of view" or what preserves or damages "my integrity" conceived (absurdly, as Socrates showed) as separable from justice. The naive relativism implicit in the claim that the ethical question is "What is good (or right) from my point of view?" was decisively criticized and left behind by analytical philosophy by, at latest, 1960, with the demonstration that it makes ethical discourse (argument, disputatio) practically senseless.

Habermas's dismissal of unrefuted moral arguments by miscategorizing them as ethical is strategically parallel to Rawls's equally unargued dismissal of the very same arguments by miscategorizing them as "not public" or "not within public reason." The nadir of misunderstanding is reached in a sentence of Rawls directed at "Catholics," strikingly similar to Habermas's invitation to "for instance, Catholics" to stand aside and allow abortion and euthanasia because such "behavior" "does not necessarily imply any damage to [y]our integrity." In Rawls's words: "They [Catholics] need not exercise the right of abortion in their own case." ${ }^{\prime 65}$ So the position is this. Citizens opposed to abortion are claiming, with some good arguments, that abortion is rather like slave-owning. (The overwhelmingly secular British parliamentary committee saw essentially the same issue of basic equality rights at stake in euthanasia.) The argument of these citizens is that the killings

63. Ibid.

64. Report of the House of Lords Select Committee on Medical Ethics (Chairman: Lord Walton), 31 January 1994, para. 237, reprinted in John Keown, Euthanasia Examined (Cambridge: Cambridge University Press, 1995), 102.

65. Political Liberalism, lvi-lvii. See also Rawls, "The Idea of Public Reason Revisited," The University of Chicago Law Review 64 (1997) 765 at 798-799. On the relation between the paperback version of Political Liberalism and "The Idea of Public Reason Revisited," see Finnis, "Public Reason, Abortion, and Human Cloning," Valparaiso University Law Review 32 (1998) 361, especially 371-376. 
whose legalization Rawls and Habermas defend are a radical, basic injustice imposed on people deprived or to be deprived of the protections of citizenship. The response(s) suggested by the argumentation of Rawls and Habermas would nun something like: "You free citizens need not exercise the right to [own slaves] [abort your children] in your own case, so you can and must recognize our law as legitimate as it applies to the rest of us (and as we will enforce it against you if you interfere)." "You people need not do any of this [killing] [slave owning] yourselves, so your integrity is undamaged and so you ought (and will be compelled) to stand aside to allow us, in the exercise of our prior right of coexistence with you, to ['coexist' with our slaves] [terminate our coexistence with these unborm children/fetuses and with people whose lives are not worth living]."166

$* * * * *$

A sound "natural law" theory has never been other than an appeal to public reasons-concerning kinds of choices consistent or incompatible with the real interests of all human persons-reasons that would command a universal consensus under ideal conditions of discourse and meanwhile are available to, and could be accepted by, anyone who is willing and able to give them fair and adequate attention, including those people whose immediate and partial interests (real or supposed) would be more or less damaged, and some or many of whose actual present beliefs would be negated, by accepting and acting upon those reasons as true. It has never been other than a theory which aspired to ensure that the content of its theses both coheres with and illuminates the natural, and the logical, and the technical (including linguistic-pragmatic), and the moral conditions under which those theses can be rationally adopted, affirmed in discourse, and acted upon in other forms of action. (It has always promoted precisely the discourse principle articulated today by Habermas.) It is therefore a theory which goes far beyond the arbitrarily "formal" and one-dimensional "practical rationality" of Kant's attempt to save it from the ravages of empiricist-utilitarian incomprehension.

No one who has followed the course of theorizing from Plato through Aristotle to Aquinas and on to the contemporary discussion of natural law theory should, I think, be tempted by the periodization which locates practical rationality's effective emergence in the philosophy of "the early modern" age-marked as it is by the long-exposed foundational mistakes of Hobbes, Hume, and (despite his best efforts) Kant. But nor should anyone

66. The failure of Rawls's and Habermas's arguments does not entail that there are no grounds for coexisting with people who authorize and fund abortions of convenience, practice euthanasia, or intend the nuclear destruction-in certain eventualities - of entire cities with their inhabitants. I have explored these matters a bit further in Finnis, Boyle, and Grisez, Nuclear Deterrence, Morality, and Realism, ch. 13; Finnis, "Public Reason, Abortion, and Cloning," at 376. 
think that the ethical and political theorizing of Plato, Aristotle and Aquinas, which those early moderns so thoroughly misunderstood, needs no improvement or overhaul.

Their theorizings left in shadow the master principle of morality and the way in which it is specified in, for example, the Golden Rule ${ }^{67}$ and in respect for every basic human good in every person and every act. They failed to follow through the implications of the fact that human life and health is one of these basic goods to be so respected and fairly promoted, and similarly the implications of the fact that religion as an appropriate harmony with the ultimate sources of existence, meaning, and value is another similarly basic good to be respected. They failed to follow through their own understanding of the equality and brotherhood of human beings with a critique of slavery properly distinguished from penal servitude. So their theorizings were disfigured with defenses of capital punishment, and of punishment (even capital) for certain false beliefs on religious issues, and with either an acceptance of slavery or at least a rather complicitous silence about it (albeit in neither case unconditional). On these and a number of other matters the tradition has worked itself pure, or is somewhat closer to having done so. It has always been, essentially, a reflection on the inherent directiveness of the basic reasons for action, and a friendly disputatio grounded in reasons, not in mere appeals to the "authority" of anyone, not even Aristotle or Plato.

\section{VII}

Reflecting on a body of work so close to natural law theory in intention and, in some respects, results, anyone may be oppressed by a renewed awareness of the nonideal character of the discourse between theorists so

67. Following Kant, and here citing only the negative version of it, Habermas holds that the Golden Rule is egocentric: Habermas, "Reconciliation through the Public Use of Reason: Remarks on John Rawls's Political Liberalism," Journal of Philosophy 92 (1995) 109, 117. He seems to forget that the Golden Rule, in classical ethics (e.g. Aquinas), takes its place as but one specification of the more universal demand that neighbor be loved as one loves oneself, and that, for the purposes of justice's basic demands, all members of the human race be treated as one's neighbors. In other words, the self-consciousness of the individual applying the Golden Rule was and is required by natural law theory (as indeed the very phrase "natural law" connotes) to "reflect a transcendental consciousness, that is, a universally valid view of the world" (id.), and to have been shaped also by morality's other highlevel specifications of the master moral principle of openness to integral human fulfilment. Attention to what is "in the interests of all" does not, however, exhaust the content of "what I would wish others to do for me, or not do to me"; part of that content is a matter of subrational (but not per se unreasonable) motivating factors, such as degree of risk aversion. See Finnis, "Natural Law and Legal Reasoning" in Robert P. George, ed., Natural Law Theory: Contemporary Essays (Oxford: Oxford University Press, 1992), 148-151. 
near (even geographically and culturally) and yet so far apart. ${ }^{68}$ The burden of history, pressing to convert each discussant into the mere voice of an "ism," is great. History's burden on discourse is magnified in another way when some parties to the discussion seem concerned to derive from history (or their interpretation of it) ${ }^{69}$ far more than others think possible without fallaciously inferring "ought" or "not-ought" from "is" (was, has been, "fact of pluralism," etc.).

Still, movement, even large movement, is possible, ${ }^{70}$ as was learned at first hand by those of us who moved on from the lifeworld of Hume, Russell et al. to take up friendly discursive residence with Plato, Aristotle, and Aquinas (alongside our respected twentieth-century teachers, whose interest in the ancients was of varying degree). Aristotle long ago taught the fruitfulness of dialogue and individual meditation in even very unpromising contexts, and the inseparable link between communicative action, inner reflection, and action of every other reasonable kind. He told, for example, of the Corinthian farmer who read the Gorgias, gave up his farm, and came to Athens to put his psychē under Plato's care.

68. The same feelings will be evoked by engagement in discourse with ecclesiastical bureaucracies and "liberal public opinion" (including its philosophically minded exponents) on matters close to people's hearts: see Nuclear Deterrence, Morality, and Realism, 367-70.

69. Some of the history which forms the matrix of Habermas's theory of law (e.g. the account of the transition to modernity in Between Facts and Norms, 145-6) seems to me to have something of the same character as today's near-universal belief that even educated mediaeval people thought the world is flat (not a sphere)-sheer fiction, fabricated by secularist propagandists of the late eighteenth or early nineteenth centuries (see Finnis, Aquinas, 4, 16; J.B. Russell, Inventing the Flat Earth: Columbus and Modern Historians [New York: Praeger, 1991]), and then handed down to educated twentieth-century people who accept it in entire innocence.

70. And one can read with profit Habermas's explorations of the "potential for selftransformation" of "liberal public opinion": e.g. Between Facts and Norms, 374ff. 
